\title{
APAC: INSTITUTION FOR THE RESOCIALIZATION OF PRISONERS
}

\author{
APAC: INSTITUIÇÃO PRISIONAL PARA A RESSOCIALIZAÇÃO DE CONDENADOS
}

\section{Luana Aparecida Barbosa Braga}

Centro Universitário UNA, Belo Horizonte/MG, BRASIL

luana.comex@hotmail.com

\section{Fernanda Carla Wasner Vasconcelos}

Centro Universitário UNA, Belo Horizonte/MG, BRASIL

fernanda.wasner@prof.una.br

\section{Cristiana Trindade Ituassu}

Universidade Federal de Minas Gerais (UFMG), Belo Horizonte/MG, BRASIL

cristianaituassu@yahoo.com.br

\begin{abstract}
The objective of this study was to analyze the method of resocialization practiced by APAC, Association for Protection and Assistance to the Prisoners stands out, an alternative to the treatment practiced in the prison system with lower cost than the common penitentiaries and superior results. In this case study, 17 semi-structured interviews were performed in APAC-Itaúna (MG), in the year of 2016. The reports were submitted to the software IRAMUTEQ for the analysis of content according to Bardin and the results showed that APAC introjects its rules, standards and beliefs in the prisoners constituting an alternative model of detention management that is efficient, complying with the Law of Penal Execution (LEP) and not violating the human rights. The results of this study showed that the institution studied offers opportunities for resocialization of the prisoner through application of the structural elements of APAC method, which is discussed in the light of the administration.
\end{abstract}

Keywords: Detention system. Resocialization. Total institution.

\section{Resumo}

Esse estudo teve como objetivo analisar o método de ressocialização praticado pela APAC, Associação de Proteção e Assistência aos Condenados (APAC), alternativa ao tratamento praticado no sistema prisional tradicional com menor custo que os presídios comuns e resultados superiores. Para esse estudo, foram realizadas 17 entrevistas semiestruturadas, na APAC-Itaúna (MG), no ano de 2016. Os relatos foram submetidos ao software IRAMUTEQ para análise de conteúdo conforme Bardin. Os resultados evidenciaram que a APAC introjeta suas regras, normas e crenças nos internos constituindo um modelo alternativo de gestão prisional que se mostra eficiente, ao cumprir a Lei de Execução Penal (LEP) e não violar os direitos humanos. Constatou-se, também, que a instituição estudada oferece oportunidades à ressocialização do recuperando através da aplicação dos elementos estruturantes do método APAC, o que é discutido à luz da administração.

Palavras-chave: Sistema prisional. Ressocialização. Instituição total. 


\section{Introduction}

The prison, an organization that has no prestige and is full of individuals who provide social risk, is ignored by many scientists, by the State and society (OTTOBONI, 2014). However, it is necessary to pay attention to these institutions, as evidenced by recent events expressed in the cover of magazines of great national movement in January 2017 (A explosão da barbárie nas prisões, Veja; O país da carnificina, Época; Os chefes do crime apavoram o Brasil, Isto é; Massacre Amazônico, Carta Capital ${ }^{1}$ ).

Aiming to resolve the crisis in the national detention system, directly related to public safety and, therefore, to society, experts have been studying alternatives that can alleviate the problems of this system. Among them is the Association of Protection and Assistance to prisoners (APAC), which adopt an alternative model of detention management. APAC is a legal person governed by private law, constituting a philanthropic institution that acts as penitentiary which administers the Centers of Social Reintegration of Prisoners (CRS), in which the detainees meet the deprivation of liberty in a worthy manner and with an efficient structure (good hygiene conditions, appropriate cells, healthy food, school and work activities, medical legal and religious assistance), from its own method as reported by Assis (2007).

Under this perspective, the APAC method adopted in these detention institutions is structured into 12 elements that aims to recover the prisoner and provide conditions for their reintegration in society, such as community participation; work; religion; family and merit. For this reason, it is considered an innovating detention institution. It should be pointed out that this method is based on a strict discipline and the humanization of the completion of liberty deprivation (OTTOBONI, 2014).

The institution is a case to be investigated for other reasons, in addition to its innovative model. One of them is the efficiency that it demonstrates in the treatment and rehabilitation of detainees: if, in the prison model policy, the monthly cost per prisoner is $\mathrm{R} \$ 3.080,00$, in APAC it does not exceed $\mathrm{R} \$ 855,00^{2}$. The rates of recurrence, in turn, are smaller: in the common prison system, 70\% of the former prisoner return to commit crimes, according to data from the National Council of Justice (CNJ), while in APAC this number does not exceed $15 \%{ }^{3}$.
Before these results, the research aims at analyzing the resocialization method practiced by APAC. Its relevance lies on better understanding a differentiated detention management model, that may be an answer to the problem of resocializing these individuals, so as not to return to crime - which is important for the prison system in Brazil and, therefore, for the very public safety. This article is structured in five parts: this introduction, literature review, the methodology, data analysis and final considerations.

\section{Literature Review}

\section{Total Institution Prison and the Detention System}

The present work focuses on the total institution, understood in this research as "a place of residence and work where a large number of individuals, living in a similar situation, separated from the wider society, for a considerable period of time, lead a closed life and formally administered" (GOFFMAN, 2015, p.11). This type of institution has peculiar characteristics: in them, after imprisonment, the individual becomes socialized, a process that uses the discipline to transform the man regarding their social conduct. Discipline is a means of domination which makes the bodies docile, obedient and helpful. With simple instruments, such as the hierarchical look which watches, the normalizing sanction and the examination, this means of domination sorts, qualifies and punishes (FOUCAULT, 2012).

The individuals introject values and beliefs of the institution, putting on stand-by previous values and beliefs. This social isolation imposed by barriers, including physical, decreases the influence that individuals there receive from the external environment, making it easier to change behavior, reason why the author refers to those institutions as "greenhouses to change people" (GOFFMAN, 2015, p.22). In this context, this socialization generates reflections for the society, changing the social relationships of these individuals.

Among asylums, convents, headquarters, old people's home and prisons, it was opted for the latter. The penitentiary organization aims to adjust socially individuals who show deviant behaviors (FISHER, 1996), i.e., it plays a key social role, in the context of public safety - or it should play. In Brazil, this reality is worrying. Factors such

\footnotetext{
${ }^{1}$ Respectively: The burst of barbarism in prisions, Veja Review; A country of carnage, Época Review; Crime bosses spread Terror in Brazil, Isto é Review; The Amazon Massacre, Carta Capital Review.

${ }^{2}$ Data informed by APAC Itaúna on October 26th 2016 through e-mail

${ }^{3}$ Available at www.bbc.com/portuguese/noticias/2014/03/140313_prisoes_apac_nm_lk. Access on Feb. 08th 2017.
} 
as overcrowding and lack of vacancies in prisons hinder actions that assure the rights guaranteed by the Law of Penal Execution (LEP), and that turn into a treatment that allows the detainees changes of values and behaviors, allowing their reintegration into society. In addition to the problems inherent in the very nature of the deprivation of liberty, the poor management of what is public, the lack of political interest, administrative and technical inabilities are highlighted as challenges, in this context (MOTTA; RIBEIRO; MOURA, 2011). The State, by not offering possibilities of rehabilitation, ends up playing a role of social exclusion (CARTAXO et al., 2013). Fisher (1996) observes that even in assuring custody of the prisoner, this disciplining project of crime reduction has proved to be incapable and limited. The prisoners live in a degrading way in a system which requires, urgently, new solutions.

\section{Resocialization of Prisoner}

As established in LEP, Law n. 7.210 dated from 1984, in its article 1, "The penal execution is intended to give effect to the provisions of judgment or decision on crime and provide conditions for the harmonious social integration of the convicted and admitted people" (BRASIL, 1984), i.e., the sentence fulfilment must provide conditions for the prisoner to integrate with society. Thus, the purpose of the deprivation of liberty is rehabilitation and resocialization of the criminal, seeking as a result way to match the evil which he has caused. The penalty application should have the effect of fear and, especially, regeneration so that the individual, upon returning to society, be useful and honest (FIGUEIREDO NETO et al., 2009).

In this context, work and professional qualification are basic elements (TAKEMIYA, 2015). After all, the insertion of these individuals into the labor market is seen as a barrier to illegal behavior, since it restricts their opportunities for misconduct and offers economic and social incentives for a life without crimes (ROCHA et al., 2012). In this sense, some authors comment on the importance of work and professional qualification for the rehabilitation of prisoners, to enable the social return because through work, the individuals ensure balance and better psychological conditioning, as well as better social commitment. Teaching them a skill is the most effective way to resocialize prisoners. (LIMA, 2010).

Also for Rossini (2015), there are some alternatives so that the Brazilian detention system solves the crisis that experiences and perform, effectively, the rehabilitation of the offender. According to the author, they include the work in prisons as resocializing measure, causing positive effects in prison; education in prisons in order to qualify the individual; the minimal intervention of the criminal law through the creation of new punishment types and the development of public policies to ensure that the State can actually achieve the goal of the sentence involving deprivation of liberty.

According to the Aulete Dictionary ${ }^{4}$, whereas reeducating means to educate again or rehabilitate the educating person, resocializing is defined as socializing again, that is, adequating group life with perception on rights, limits, sympathy, among others. Thus, reeducation is a form of resocializing.

\section{APAC- Association of Protection and Assistance to Prisoners}

Founded in the 70's by the lawyer and journalist Mario Ottoboni and a group of participants of the Pastoral of Reconciliation from São José dos Campos (SP), the APAC Method offers guidelines that offer to the Offender possibility of recovery, in order to protect society and promote social justice. The appreciation of the discipline, respect for the human person and the proper treatment of the offender, already provided for under the Law of Penal Execution (BRASIL, 1984), are some of the factors that enable the success of this model, whose motto is "Kill the criminal and save the man". According to Ottoboni (2014), the method is based on the twelve elements and none of them can be replaced or excluded: (i) Participation of the community; (ii) Recovering helping the offender; (iii) Work; (iv) Religion; (v) Legal assistance; (vi) Health care; (vii) Human enhancement; (viii) The family; (ix) The volunteer and the course to their training; (x) Center for social reintegration; (xi) Merit; (xii) The journey of liberation with Christ.

Other circumstances help make a group of aspects that turn this method differentiated. According to Soares (2011), in the APAC, there is no police presence nor of the prison agents, the prisoners themselves possess the keys to the cells and are responsible for the security of the site. They also do not wear uniforms, but common clothes, they are called by their names, do not wear an identification badge, besides cutlery during meals.

${ }^{4}$ Available atwww.aulete.com.br. Access on: Feb. 15th 2016 
Faria (2011) describes some characteristics of this correctional project, such as, individualization of conviction; effective participation of the local community, through volunteering; only one prison that offers three criminal schemes: closed, semi open and with independent facilities and appropriate to the activities carried out in each one of them; absence of weapons. The author also highlights the activities performed by the offender according to the conviction regime that the same is inserted to. Campos Filho (2013) classified the proposals adopted by APAC method in: (i) preparing the prisoner to return to social life; (ii) ensuring the society to live with a resocialized individual and (iii) monitoring the resocialization inmate and his family.

In addition to the human appreciation, work is a structuring element of this method, and the resocialization inmate is assisted with labor and professionalizing activities and workshops that prevent the idleness of those convicted and allow the discovery of their merits (OTTOBONI, 2014). It is all about a socializing action that improves the prisoner's self-esteem and helps him identify his skills for the day-by-day work (SANTOS, 2013).

Religion is another important point. According to Ottoboni (2014), in APAC no religion is imposed, but it is necessary that the detainee seeks an experience with God and have a religion. This is target of criticism because, although the religious bond is type of escape valve for the prisoners, as stated by Coutinho (2009), the obligation of the prisoner to become a religion believer is contrary to Article 24 on LEP, according to which "No prisoner may be required to participate in religious activity." (BRASIL, 1984).

APAC method is also criticized for not suiting to any prisoner, not taking into account the needs of the prison population as a whole (FALCÃO; CRUZ, 2015). In this proposal, the convicted person must accept the guidelines, follow the rules established and adapt to the discipline of criminal treatment. Despite of the benefits offered by such model, there are prisoners that are ill-suited to its proposal and ask for their return to the common detention system.

Despite these issues, the method had its results recognized by the United Nations (UN), through the Prison Fellowship (SOARES, 2011). The author highlights that, in this method, the cost value per prisoners corresponds to $1 / 3$ of that of the common detention system. According to Campos and Santos (2014), in Brazil, there are 100 APAC whose maintenance cost is $40 \%$ of the common detention system. Another relevant factor is that $70 \%$ of individuals who spend conviction of liberty deprivation in APAC get jobs after the conviction, indicating that this is a successful experience.

\section{Methodology}

This research had qualitative approach and descriptive character. A case study was performed (VERGARA, 2012), having as a unit of analysis the male APAC from the Judicial District of Itaúna, in Minas Gerais. Due to the good results in the method application, this APAC became a world reference, fact that motivated its choice as research object.

As data collection instruments, semi-structured interviews were used through accessibility until saturation, made from scripts previously prepared for each type of subject: (I) prisoners of closed and semi-closed regimes; (ii) management (directors of APAC Itaúna, Brazilian Fraternity of Assistance to the Damned (FBAC); (iii) public power (judge of penal execution of Itaúna). The respondents were categorized according to the penalty regime (closed, semi-opened, "not applicable" for those in management and public power) and the type of individuals (manager, prisoner, public power).

After the approval of this project by the Committee for Ethics in Research (CEP) of the Hospital Foundation of the State of Minas Gerais (FHEMIG), the interviews were performed during the period from October to December 2016. Starting with a brief statement about the purpose of the study, the ethical aspects specified in the Informed Consent Form (ICF) were recalled, in two counterparts previously signed, one of which was delivered to the person interviewed. Thus, it was obtained the permission of the interviewees on their speaking record. Subsequently, these were transcribed in full and subjected to content analysis and formulation proposed by Bardin (2016), using the software Interface de $\mathrm{R}$ pour les analyses Multidimensoionnelles de Textes et de Questionnaires (IRAMUTEQ). The software has proposed 5 semantic classes, separated by the lexicon as described in table 1 and the predefined variables for this study (penalty regime and type of individual), providing the segments of typical texts to justify the formation of each of the five classes and allowing the interpretation and analysis of this information. For example, the word APAC appeared in total 251 times, being 126 times in class 1, referred to as the methodology APAC, representing 50.2\% of the total, equivalent to $\mathrm{X}^{2}=56.24$. It is for this reason that the word APAC is in class 1 along with the words judge $\left(X^{2}=50.86\right)$, method $\left(X^{2}=47.14\right)$, methodology $\left(X^{2}=44.21\right)$ and course $\left(X^{2}=40.5\right)$ which had greater representation, justifying the sense of being with greater emphasis and belong to the same class. Similar thought was used to understand the other classes. 
Table 1. Identification of the words in the classes

\begin{tabular}{|c|c|c|c|c|}
\hline Words & EFF. St & EFF. Tot & $\%$ tot & $X^{*}$ \\
\hline APAC & 126 & 251 & 50.20 & 56.24 \\
\hline Judge & 22 & 22 & 100.0 & 50.86 \\
\hline Method & 33 & 42 & 78.57 & 47.14 \\
\hline Methodology & 24 & 27 & 88.89 & 44.21 \\
\hline Course & 41 & 61 & 67.21 & 40.5 \\
\hline \multicolumn{5}{|c|}{ Class 2 - Human Appreciation } \\
\hline Words & EFF. St & EFF. Tot & $\%$ tot & $X^{2}$ \\
\hline Help & 46 & 73 & 63.01 & 49.78 \\
\hline Person & 95 & 203 & 46.80 & 46.07 \\
\hline Love & 22 & 26 & 84.62 & 43.99 \\
\hline Talk & 107 & 242 & 44.21 & 42.83 \\
\hline Same & 76 & 164 & 46.34 & 34.32 \\
\hline \multicolumn{5}{|c|}{ Class 3 - Recovering Helping Recovering } \\
\hline Words & EFF. St & EFF. Tot & $\%$ tot & $X^{2}$ \\
\hline Use & 12 & 13 & 92.31 & 78.29 \\
\hline Exam & 10 & 12 & 83.33 & 56.93 \\
\hline Right & 13 & 21 & 61.90 & 48.95 \\
\hline Drug & 19 & 40 & 47.50 & 47.67 \\
\hline Purpose & 8 & 10 & 80.0 & 43.03 \\
\hline \multicolumn{5}{|c|}{ Class 4- Common Prison System } \\
\hline Words & EFF. St & EFF. Tot & $\%$ tot & $X^{2}$ \\
\hline Crime & 51 & 69 & 73.91 & 282.95 \\
\hline Commit & 25 & 34 & 73.53 & 134.02 \\
\hline Common & 15 & 19 & 78.95 & 87.51 \\
\hline Prison & 13 & 17 & 76.47 & 72.56 \\
\hline Bandit & 8 & 8 & 100.0 & 62.85 \\
\hline \multicolumn{5}{|c|}{ Class 5-APAC's routine } \\
\hline Words & EFF.St & EFF. Tot & $\%$ tot & $\mathrm{X}^{2}$ \\
\hline Time & 42 & 68 & 61.76 & 88.19 \\
\hline Take out & 27 & 39 & 69.23 & 68.04 \\
\hline Get up & 15 & 15 & 100.0 & 66.41 \\
\hline Clothing & 19 & 23 & 82.61 & 63.35 \\
\hline
\end{tabular}

Source: Research Data, 2016.

Note: EFF. St = number of UCE's which contains the word used in the Class; EFF. Tot $=$ number of UCE's of Textual Corpus which contains the word; \% Tot. = percentage of UCE's of the class in relation to the textual corpus and $\mathrm{X}^{2}=$ Chi-square test of association word/ Class.

After the analysis of each class and the set of words that comprised them, they were presented in the following order: category 1: APAC method management; category 2: APAC's routine; category3: Human appreciation; category 4: Recovering helping recovering and category 5: Legal structure, crime and traditionality. All of them are in details at the next topic.

\section{Results Analysis}

\section{Category 1: APAC Method Management}

This category showed that the APAC method management is performed by several individuals from different spheres. Among them are the judge, APAC's FBAC's directors, the members of the Council of Sincerity and Solidarity (CSS), the person in charge of security and the own prisoner have specific roles for the achievement of positive results that will directly reflect on the functioning of APAC and the reintegration of prisoner to society.

\begin{abstract}
- "There are several reasons, the unconditional support of the judiciary and the Public Ministry are factors that directly contribute to the success of an APAC. You have a decentralized management model, where staff, volunteers, society, prisoners work in a uniform manner, in a harmonious manner, this also contributes directly to success. The total application of 12 basic elements are important factors for the methodology success. So, there are several". (Interviewee 1 , manager).
\end{abstract}

The management of APAC method is based on the acceptance by the prisoner and in compliance with the standards imposed by a rigid discipline based on work and, also, in love and trust. Therefore, other authors also care, as shown in their speaking:

-"Discipline is done by the own prisoners, which is not easy as well. But we are obliged to have it, wanting or not. In here if we do something wrong, everybody will pay. It is collective. It is not like in the common system, which is individual. Not in here, if one makes anything which disturbs somehow, everybody will pay." (Interviewee 6, semiopened regime).

- "We need to have our beds clean, the bathroom, do not leave towel, underwear hung... Because there is the cell inspection, which will ask: "who does it belong to"? Then the person is punished, did you get it? In the afternoon, at four o' clock, we have leisure time, watching a TV, playing soccer like the guys there playing, a shuttlecock, you cannot because you have left is... for example, dirty, left him there, you cannot, cannot thing train inside the cell that you are punished, impaired anyway. One little mark you do not leisure time; two little marks, one week; three little balls, two weeks... Every day, every day there are the workers on duty.... Every day... We ourselves take a look, we are older" look, 
your underwear is hung, did you get it? That is, it, otherwise... everybody is harmed.... It is about one helps the other, did you get it? (...)" (Interviewee 10, closed regime).

The content analysis in this category also showed the importance of education and professionalization for the reintegration of the prisoner to society and the labor market, in line with the studies of Lima (2010), Takemiya (2015) and Campos (2015), being necessary to improve partnerships of APAC with educational institutions and companies from different segments so as to maximize these opportunities.

\begin{abstract}
- "Yeah..I think that the more courses, more conditions of recovery in APAC, less trouble he will cause when he returns to social life, especially the semi-open regime, where it will be created there a bodywork, tin-shop and a tin-shop also with the partnership of the Railroad Center Forest, so if everyone analyzes well, the prisoner, he often leaves and recidivates because he comes out and speaks - "enough out there and I will not have employment" and the APAC offers us the qualification too." (Interviewee 11, closed regime).
\end{abstract}

In addition, it was possible to identify the perception of prisoners on this process of resocialization, when they notice the importance of training and qualifications for the reingress into society and the labor market, as also observed in studies of Campos (2015). This was illustrated in the statements below:

- "But this process involves other activities, right? The education, for example, there the teaching is required, I don't know if realized, but there practically everybody studies, right? And that education has a vital role due to being of a lower level, there are illiterate, with two years of schooling, isn't it? And there have been cases, several people who went there were illiterate and came out with College Degree... (...) And this we believe that whoever comes there and leaves with a training, for example in Law, leaves another person, in other conditions for out there, to be admitted into the market and not return to commit other crimes." (Interviewee 17, public power).

\begin{abstract}
- "Like my brother went through here, a friend of mine, very close friend of mine went through here and he made a course here to work with ore saw, left employed, by SESI. I think there is a partnership with SESI, SENAI, I mean! And he came out here employed with a cool profession..." (Interviewee 13, closed regime).
\end{abstract}

According to reports submitted in this category, the APAC method management it was found that this method is applied by managers as described in the Manual of Systematization of their Processes (APAC, 2015a) and the Disciplining Regulations (APAC, 2015b). This fact is confirmed by the lessons of the method and the daily activities, and is characterized as a ressocializing method whose goal is to return the prisoner to society after the enforcement of the sentence, what can be seen by testimonies of the prisoners themselves.

\begin{abstract}
- "There is a class on the APAC method, which is given in closed regime, during two months and during these two months you have two tests, you always have a notion of what is a... where it was founded, these kinds of things.... Then you go to semi-open regime, and those who had the tests in the closed regime do not need to them again here, and there you go, (....)." (Interviewee 4, semi-opened regime).
\end{abstract}

In this speech, the interviewee mentions one of the three mechanisms typical of the discipline, which is the exam (FOUCAULT, 2012), in the figure of the tests that need to be done after the course on the method. In this case, they are used to check and ensure that the prisoners have learned its main points. In other words, it is an instrument of socialization, which helps to regulate the detainees.

In summary, this category showed that the method is managed by several individuals with specific roles and necessary for achieving good results in the functioning of 
APAC and in the process of resocialization of prisoner. In addition, it was necessary the acceptance of the rules and guidelines of the institution by the detainee. Another relevant factor presented in this category was the importance of education and professionalization for the reintegration of the prisoner into society and the labor market.

\section{Category 2: APAC's Routine}

The content analysis of this category showed the day to day in APAC, through the application of this method, which seeks to rehabilitation of the convicted person, not losing its punitive function. The obligation of the prisoner to fit and follow the norms of the institution contributes to the transformation of the individual for the good.

\begin{abstract}
- "Everyone wakes up at 6 o'clock in the morning because at 7 o'clock there is first socializing act, the socializing act is composed of call roll, prayer and warning. After that, everyone has breakfast, at 8:00 a.m. there is human appreciation until 9, from 9 to noon we work, from noon to one we have lunch, 1 to 3 we work, 3 o'clock we have a snack, 3 and half we go back to work until 5 . From 5 to 6 we have leisure time, because at 6 we have school, the school goes from 6 to 7 , at 7 we have dinner, 7 and thirty we go back to school until half past 9 . And 10 o'clock, we need to be ready to sleep. So, it is really tough, but it is gratifying." (Interviewee 2, semiopened regime).
\end{abstract}

The managers interviewed stated that the therapies used in APAC is an efficient social tool to recover the prisoners, to protect society and to promote justice. In addition, they emphasize that the involvement of the community and the volunteers contribute to this new project of life of prisoners and assure its prisoners duties imposed by the Law of Penal Execution (LEP), in accordance with the studies of Santos (2013).

The day to day activities in APAC facilitates the realization of structural elements of the method and contribute to the prisoner's resocialization, giving him the opportunity to understand the reasons that led him to the life of crime and allowing, through these reflections, the adoption of initiatives that will lead to a change of life (ROSSINI, 2015).

- "This adaptation because there is
then... the others work eight hours per
day and it has no such activity unless
he wants to stay there, he has to stay
there as long as possible, that is why
we can achieve our goals in these three
months, right? You arrive, you are not
used to this system, you arrive and
then you need to work eight hours
a day, you are not used. Then in the
morning, he has human appreciation
class, in the first act, the method
school and then only after that he will
start to work at the labor therapy. One
part of the day he will study, and the
other part he will work." (Interviewee
8 , manager).

In this category, some of the 12 elements of the method were identified, namely, work, family, volunteer and their training, technical and legal assistance and community participation, principles relevant to the experiences of the subject in this prison system.

- "Because the way we are treated
in here, our family... Some of them
think about family, right? Because
out there, the family goes through
a lot of humiliation, and in here no,
the family has been hosted, like in the
Mother's Day there is lunch for the
family, Father's Day.... There was the
children's day.... So, they do the most
they can..." (Interviewee 16, closed
regime).

In short, this category has presented the activities of daily living in APAC, with details about what the day-to-day routine of resocialization inmates is like and how some activities assist in the resocialization process. 


\section{Category 3: Human Appreciation}

The category Human Appreciation addressed issues such as: respect for the family, society and trust, (re) construction of values, religion, reward for activities of daily living (merit). The analysis of this class showed that most respondents understands the importance of the value given to human beings and that this valuation is due to the set of 12 elements of the method APAC for enforcement of the sentence in a decent way, and also for their resocialization. This fact is in accordance with the study of Camargo (2006), upon emphasizing that the process of human appreciation assists in the recovery of the prisoner.

- "Everyone is treated in a humane manner, is called by name, wears their own clothes, has their dignity, that is the big difference!" (Interviewee 11, closed system).

"From the moment they trust on us, they want to help us, not just to harm. Helping in what ways? Bringing human appreciation, bringing people to be talking with us. It is different, you know? And also you help to a great extent, too. We get.... We want to believe, the others believe in us, that we can change, that is really important too..." (Interviewee 7, semi-opened regime).

- “(...) Because there is a lot of trust, they flee a little because we trust a lot and they trust to the point of giving us the key. So... This gets commitment from us, right?" (Interviewee 1, manager).

In spite of the statements not mentioning directly health as an important resocializing element, it was found that the APAC offers salubrious and basic conditions to the recovering during the execution of the sentence, as exemplified in several speeches, during the interviews: having a bathroom with hot shower water in the cells, have a single bed, the cafeteria for food, ice water, and the infirmary.
- "Because here you have dignity, you eat with forks, you drink soda, cold water... Eat what you want.... Sleep... peacefully, in the jail, no! In the jail, it is bad food, you do not even eat... In a cell the room fits 12,13 people, and there are 32, 33 people, it is crowded. In the other..., one bed to sleep, hot water..." (Interviewee 10, closed regime).

In this way, it was observed the fulfilment of the duties imposed by LEP and the $6^{\text {th }}$ element of the method, health care. Contrary to the reality presented at APAC, Cartaxo et al. (2013) showed that overcrowding in prisons of the conventional system affects mainly the medical care of prisoners.

In this research, the human appreciation proposed by APAC is present in its activities, which allow the prisoner to learn social, moral and ethical values, restoring family and social bonds, without losing its punitive function. It can also be seen that the proper and dignified treatment to the prisoner, in addition to benefiting him and his family, impact on society as a social innovation in the face of the remarks of Bignetti (2011).

- "The greatest differential is the family, the respect you have for the family, which there is not any there. I myself, I have 04 daughters and I only went to see my daughters after I won the first descent. Over these 04 years that $\mathrm{I}$ had been in jail. Because I did not let them go. Because I arrived there and got naked, and it was such a mess. Suddenly there may be a rebellion... how is your family inside there... and unfortunately, the prisoner has to make a claim will make the time you know that... right? ... So... we get afraid, and let it go and let it go... but not in here, you know that you have... The first support is your family, for all that you are doing if you do not have a support which is the family... here we have more confidence to let the children come... (...) APAC is completely... at this point it is completely different." (Interviewee 6, semi-opened regime). 
In short, the human appreciation, the $7^{\text {th }}$ element of the method, focuses on the internal development of the prisoner and offer decent and healthy conditions for the prisoner during the execution of the sentence.

- "Because the APAC's food is good, no one wants to escape... APAC always preaches, love and trust nobody escapes. It is, I believe that this beloved that Mario always uses, it is primarily in the escorts, we are shackled by the heart and escorted by Christ, I think that from the moment that we chose for the APAC everyone is grateful the way it treats us, nobody will want to flee and leave and go back to the conventional system and go through everything again... (...)." (Interviewee 11, closed regime).

\begin{abstract}
- 'That is because you do not have a reason to space, because in here they do not work overwhelmed. In here they have a day-by-day and society schedule, right? You have to wake up early and has to work, equal to the society out there too. You have to work and must have a time to feed, same thing as if you were on society as well. So, I think that in here you are ready to go to the street. More quiet, more adapted to society..." (Interviewee 7, semi-opened regime).
\end{abstract}

In this category, it was found that the APAC delivers what is established in the Law of Penal Execution, $n^{\circ} 7.210$, July $11^{\text {th }} 1984$, providing humane treatment for prisoners through the guidelines set forth in the method it used.

\section{Category 4: Resocialization inmates helping resocialization inmates}

This class covered the following topics: project of life, experience from the mutual aid during the period of adaptation, daily activities; life, purpose, new values and religion; religion and God.
- "Too many little rules, kind of any little thing is a thing of cutting... such as for instance leisure which I speak is the benefit of watching a TV... One thing that it is, therefore, any little thing... For example, any quarrel when it happens it harms everybody, right? It harms everybody and we have to help each other. Being that the Decalogue of peace even says is "helping... recovering, helping recovering" to walk together with one another." (Interviewee 7, semi-opened regime).

This category showed that relations of coexistence among the prisoners, associated to the practice of tolerance, solidarity and brotherhood, structure the $2^{\text {nd }}$ element of the method (Resocialization inmates helping resocialization inmates). These relations constitute a learning to live in society, which reinforces the theories of Ottoboni (2014) and highlights the importance of harmony among the twelve elements proposed by the method adopted in APAC.

\footnotetext{
- "So, the form that treated me here, equal to this difficulty for me is... that the beds are bunk beds and there are people who hold 5 or 6 months to move to the bottom, right? Then, the boy who was at the low bed ceded his place to me...(...), the normal was that I would have lied down on the top, right? And the guy gave his place for me. And during feeding time, they take my food for me, every day they take, because it is difficult for me there in time to serve the food, they take, lead to me there at the table..." (Interviewee 16, closed regime) ${ }^{5}$.
}

For Santos (2013), these practices also contribute to establish limits, rules and responsibilities, individual and collective, being a differential in relation to the common system which has, as daily routine, the sun bath and idleness, which are the only activities planned, contributing to the learning of criminal practices, anger and hatred. Besides, the spirituality was evidenced during the interviews as a necessary tool to obtain a new life. Religious bond helps alleviate the difficulties experienced in the execution of the 
sentence, as well as provide a hope to have a better life (COUTINHO, 2009).

\begin{abstract}
- "It is... we have religious worship, here there is no discrimination on the basis of creed, the pastor comes, makes the worship of the gospel on Saturday; the father and more ministers come to the celebration of the Mass, then there is all this whole monitoring." (Interviewee 5, semi-opened regime).
\end{abstract}

Finally, in this category coexistence practices that were presented among the prisoners based on sympathy, brotherhood and tolerance. It is important to highlight that such practices are taught by the Members of Sincerity and Solidarity (CSS) and the resocialization inmates themselves.

\section{Category 5: Legal structure, crime and traditionality}

This class presents elements of the common detention system described by the interviewees, among which the inhumane treatment suffered by them and by the lack of structural conditions and physical conditions of prisons and violence imposed by security agents. The prisoners went very emotional in this moment.

The content analysis of this class has demonstrated that the detainees know to differentiate between traditional system and the APAC's one, being inevitable the comparison between the usual procedures to a common prison policy with those taken in accordance with the method. In this context, the speech of the interviewees shows the preference in serving a sentence in APAC because of the physical structure, the humane treatment they receive and by establishing their activities on the rights and duties provided for in LEP. need to face one more day ahead of you with a very crowded cell. In here it is different, each one sleeps in their own bed, we have human appreciation class, this is the reeducation I talked about $\backslash$. That is why $=$ the recurrence is much lower." (Interviewee 2, semiopened regime).

\begin{abstract}
- "You know you have to do humiliating procedures, vexatious frisking, so everybody knows what happened, but the family do not cry in order not to pass weakness for us." (Interviewee 2, semi-opened regime).
\end{abstract}

In the common comparison between the conventional and APAC systems, the ideas related by the interviewees to the common system were violence, overcrowding, separation of prisoners by type of crime committed, laziness, university of crime, rebellions and riots, lack of structure and hygiene in establishments, similar to that observed by Callegari (2009). The violation of human dignity (OLIVEIRA, 2008) and the neglect of society and the government (ASSIS, 2007) also appeared in the reports, such as the characteristics of the system. Lastly, all of these factors present in the common prison system policy affect the resocialization of the prisoner, being in line with the observations of Rossini (2015).

\begin{abstract}
- "No One improves their life, because down there you are evil, are humiliated, your family is humiliated. Down there, you will be leaving more disgusted." (Interviewee 10, closed regime).
\end{abstract}

- "A cell that fits 10, there are 30. How can you have a calm mind in a place that you don't have a peace of mind to sleep? So it is very complicated. You wake up very early, thinking that you

\begin{abstract}
- "I think that a lot of times by... when you arrive here, self-esteem, because you're in the common system, (...), you are treated, let's say so, as a garbage, the scum of society. (...)." (Interviewee 14 , closed regime)
\end{abstract}

\footnotetext{
${ }^{5}$ Recovering with leg disability and wo uses crutches to get around. In the common system, he cannot use such equipment, reason why he was transferred to APAC Itaúna.
} 
- "Great... Here there are several things that differentiate, equal as well, help a person to improve. - In there it is different, there exits drugs all day long, it is... they only speak of crime... that is... You just have this bad thing and not here, here you work, you occupy the mind, studying... there is human appreciation... there are several things that offer for you to change... other ways, right?" (Interviewee 3, semiopened regime).

\section{- "Even for you to go to the Sun, you are handcuffed, loose dogs, the Rottweilers among the people, when you see there is trouble, and sometimes there are these riots, right? And the guys, just like I saw lead a guy to die for 46 stabs with sharp object this size...you know? You do not go out of their way to freedom with the head too good to tell you the truth." (Interviewee 13, closed regime).}

Thus, it was evidenced in this class that the systems presented are very different. It should be noted that the APAC closely follows what the LEP establishes, by granting rights and demanding duties laid on the prisoners. In other words, the APAC is based on legislation to establish its institutional procedures. In summary, this category revealed comparative aspects between the common detention system and the APAC method.

\section{Final Considerations}

This research showed, through the analysis of categories, that the APAC is an alternative model of detention management that, through its method, aims at applying punitive character in a dignified manner, providing conditions for the prisoner to be resocialized and get his reintegration into society after the completion of the deprivation of liberty, as laid down in LEP. The data analysis showed the discipline as a determinant factor for which the institution reaches its results, in line with the characteristics of a total institution and the studies of Foucault (2012). This can be noticed in the interviewees' speeches and also in case of the strict obedience to the disciplinary rules of the institution, accepted in term of the commitment that the prisoner signs, as he ingresses into an APAC.

After the interpretation of the results, it is clear that the APAC, by means of the twelve elements that structure the APAC's treatment, introjects its rules, standards and beliefs to the convicted people, respectfully called resocialization inmates. This institution makes bodies docile and introjects values as proposed by its method, with the values acquired during their primary socialization, first experience for a new project of life. It is also possible to consider that some interviewees were not successful in the socialization process of the traditional prison system, being the APAC understood as its first effective socialization. Before being arrested, the individuals presented inadequate behavior to the social coexistence. From the introjection of these new values, taught by APAC, the idea is that the prisoners learn to live in society in accordance with rules and acceptable standards of conduct.

With this purpose, the institution offers tools, through the application of the elements of this method, which enable the prisoner resocialization. These tools teach the prisoner social, moral and ethical values, allow and encourage the restoration of family bonds, as well as providing an opportunity to study and qualification. It should be emphasized that religion, the basis of the method, is also an important element so that the resocialization inmate is resocialized. This consists of a problem, since that obliging the prisoner to have a belief goes against what the legislation says, but having it is one of the process pillar. To put it another way, how to extend this model to atheists? It is a very appropriate reflection and for which there is still no response.

The research also showed that the routines and activities developed by the prisoners in their routine in APAC play a major role socializing, contributing to their reintegration. In addition, there are external factors such as family, society and volunteers, elements of the methodology necessary for the process (OTTOBONI, 2014; SANTOS, 2013). It is important to emphasize the relevance of society in that socializing role, especially in creating partnerships with the institution to offer professional training courses and vacancies for the convicts and/or prisoners who have already served their sentence (LIMA, 2010; CAMPOS, 2015; TAKEMIYA, 2015). In this regard, the work appears in the literature as a fundamental element in the recovery and resocialization of prisoners (ROCHA, LIMA and FERRAZ, 2013, OLIVEIRA, 2013, ROSSINI, 2015 and CNJ, 2015). At the investigated institution, it was no different. APAC of Itaúna has partnerships with some institutions such as FBAC, Program New Directions, 
Court of Justice of Minas Gerais (CNJ), Minas Institute for Peace, SESI and SENAI. Others may be thought of and will be required to maintain this process.

All of this is done to ensure the fundamental rights and guarantees provided for in the Constitution of the Federative Republic of Brazil of 1988, as well as the Law of Penal Execution. The method presents a project of life for the prisoner proposing mutual help, brotherhood and solidarity, love and trust, which are reflected in the possibility of resocialization, within a proposal to promote social justice (OT'TOBONI, 2014), reducing crime and, therefore, protecting society. In spite of being the target of some criticism that need to be considered, the results show that it is an experience of successful resocialization.

Unlike this reality, but very present in the results of this study, the statements have portrayed the day to day in a conventional prison as a form of comparison between systems and as an indicator that the traditional prison presents serious barriers to play its resocializing role. Its reality of violence is frequent in the press, especially nowadays that the country has experienced a crisis in the detention system. The ease of prisoners to obtain drugs, weapons, cell phone, money and the domain of the criminal factions in prisons make riots and massacres easy aggravating the situation (ASSIS, 2007; CALLEGARI, 2009; ROSSINI, 2015). This crisis reinforces that there is still much to be observed for the deprivation of liberty to fulfill one of their greatest purposes, which is the prisoner's resocialization. To do this, however, it seems necessary among several other initiatives - a cultural change in the penitentiary system. This change needs to be able to change paradigms and combat radicalism, by which the detainees would not be worthy of humane treatment, according to the crimes they committed.

The results of this study have brought managerial implications from the observation that APAC method is a viable and efficient alternative in the penitentiary system. In addition, they indicated some challenges for the managers regarding the method. Among them, improve it from consideration of those convicted who do not fit the method; invest in the identification of prisoners with a profile consistent with the structural elements of the method; increase the adoption of this method to other Brazilian regions. In this context, the State must develop public policies that complement the work carried out by APAC, supplying its weaknesses and favoring the placement of the prisoner in the labor market.

Thus, it is important to say that this article brings unpublished contributions, as long as it investigates the structure and dynamics of a total institution, from an innovative method in the prison system, which attends to a social demand. Resocialization in this environment is the object of study in different areas of knowledge, such as law, medicine, psychology, sociology, but has not yet received enough attention from the administration. This area of knowledge has a lot to contribute. Support can occur in several ways, since the option to have this type of institution as a focus of study, with the aim of copying the best practices, along the lines of what happens with commercial ventures and is called benchmarking, until initiatives that bring to entities such as APAC knowledge in this field, including all its areas: strategy, people, marketing, finances. Organizational studies that turn to this type of initiative may, as defended here, present social relevant impacts.

This research showed, also, that the prison protects the society from criminals, but this protection occurs for a limited period of time, not solving the problem definitively. Therefore, the issue of resocialization is an urgent aspect to be worked, since it is essential for the success of the punitive measure of liberty. If, for this reason, the APAC method is a good option for the administration, reception, resocialization and reintegration of the convict, and if it is also a model which, in economic terms, is less expensive and more effective, this article concludes with a question: why not refine it and replicate it? Studying it, understanding it, subject it to criticism seems basic. In this sense, that is what this research aimed to do.

As a suggestion for future studies, an apparent contradiction may be noted: total institutions function from, among other things, minimizing individual differences and environmental influences (GOFFMAN, 2015). On the other hand, APAC, although it can be considered a total institution, adopts a discourse of valorization of the life, of the human person and of its individuality, which sounds incoherent and deserves further reflections. Thus, a study that is dedicated to exploring and understanding this paradox seems promising.

\section{References}

APAC, 2015a. Método APAC - Sistematização de

Processos. Available at: <http://bd.tjmg.jus.br/jspui/ handle/tjmg/7821>. Access on 15 out. 2015.

APAC, 2015b. Regulamento Disciplinar APAC. Available at: $<$ http://www.criminal.mppr.mp.br/ arquivos/File/ExecucaoPenal/Mateiral_de_Apoio/ 
APAC/Regulamento_Disciplinar_APACs.pdf $>$ Access on 15 out. 2015.

ASSIS, R. D. de. A Realidade Atual do Sistema Penitenciário Brasileiro. Revista CEJ, Brasília, v. 39, n. 2, p.74-78, dez. 2007.

BARDIN, L. L'analyse de contenu. Paris: Presses Universitaires de France, 2016.

BIGNET'TI, L. P. As inovações sociais: uma incursão por ideias, tendências e focos de pesquisa. Ciências Sociais UNISINOS, v. 47, n. 1, Jan. Abril 2011, p. 3-14.

BRASIL. Lei no 7.210, 11 jul. 1984. Institui a Lei de Execução Penal. Diário Oficial da União; Brasília, 1984 Jul 13. Available at: <http://www.planalto.gov.br/ccivil_03/ leis/L7210compilado.htm> Access on: 21 out. 2015.

CALLEGARI, A. Prisão deve ser vista como exceção, e não como regra. Revista do Instituto Humanitas Unisinos, São Leopoldo, v. 293, p.1-2, 18 maio 2009.

CAMARGO, V. Realidade do Sistema Prisional no Brasil. In: Âmbito Jurídico, Rio Grande, IX, n. 33, set 2006.

CAMPOS, S. M. Cardita Silveirinha. Sistemas

Prisionais Europeus. 2015. 113 f. Dissertação

(Mestrado) - Curso de Direito, Faculdade Nova de Lisboa, Lisboa, 2015. Available at: <https:/ / run.unl.pt/ bitstream/10362/15168/1/Campos_2015.pdf > Access on: 03 nov. 2016.

CAMPOS, A. C. A. de; SANTOS, E. L. dos. A Ressocialização do Preso junto à Sociedade. Revista Científica Eletrônica do Curso de Direito, Garça, v.6, p.1-9, jul. 2014.

CAMPOS FILHO, M. L. de. Lei de Execução Penal - Disposições Finais e Transitórias. In: SILVA, J. R. (Org.). A Execução Penal à Luz do Método APAC. Belo Horizonte: Tribunal de Justiça do Estado de Minas Gerais, 2013. p. 364-371.

CARTAXO, R. de O.; COSTA, G. M. C.; CELINO, S. D. de Matos; CAVALCANTI, A. L.. Panorama da estrutura presidiária brasileira. Revista Brasileira em Promoção da Saúde, Fortaleza, v. 26, n. 2, p.266-273, 2013.

CNJ.CONSELHO NACIONAL DE JUSTIÇA. Agência do Conselho Nacional de Justiça, 2015. Disponível em: http://www.ipea.gov.br/agencia/images/stories/PDFs/ relatoriopesquisa/150611_relatorio_reincidencia_criminal. pdf. Acesso em 15 de junho de 2016.

COUTINHO, A. de S. L. Família, Trabalho e Religião:
Fatores de reintegração do detento? Um estudo comparativo e descritivo entre o sistema prisional comum e a Associação de Proteção e Assistência aos condenados. 2009. 133 f. Dissertação (Mestrado) - Curso de Economia Doméstica, Universidade Federal de Viçosa, Viçosa, 2009. Available at: <http:/ / alexandria.cpd.ufv. br:8000/teses/economia domestica/2009/226227f.pdf $>$. Access on: 20 ago. 2016

FALCÃO, A. L. S.; CRUZ, M. V. G. da. O Método APAC - Associação de Proteção e Assistência aos Condenados: análise sob a perspectiva de alternativa penal. VIII Congresso CONSAD de Gestão Pública, Brasília, p.126, maio 2015.

FARIA, A. P.. APAC: Um modelo de humanização do sistema penitenciário. Âmbito Jurídico, Rio Grande, v.87, p.1-2, abr. 2011.

FIGUEIREDO NETO, M. V.; MESQUITA, Y. P. V. O. de; TEIXEIRA, R. P.; ROSA, L. C. dos S. A ressocialização do preso na realidade brasileira: perspectivas para as políticas públicas. In: Âmbito Jurídico, Rio Grande, XII, n. 65, jun 2009.

FISCHER, R. M.. (coord.). Processando as Pessoas: Estratégias de Socialização Organizacional. In: FLEURY, M. T. L.; FISCHER, R. M.. (Coord.) Cultura e Poder nas organizações. São Paulo: Atlas, 1996.

FOUCAUlT, M.. Vigiar e Punir. 20. ed. São Paulo: Vozes, 2012.

GOFFMAN, E.. Manicômios, prisões e conventos. São Paulo: Perspectiva, 2015.

LIMA, E. C. B.. A ressocialização dos presos através da formação profissional. DireitoNet, Sorocaba, p.1-5, 14 jul. 2010.

MO'TTA, L. E.; RIBEIRO, L.; MOURA, A.. Políticas de reinserção Social de condenados de Minas Gerais: um estudo de caso. Quaestio Iuris, v. 4, n. 1, p. 583, 2011.

OLIVEIRA, C. S.. De Condenado a

Recuperando: Convergência entre LEP e método APAC. 2008. 101f. Dissertação (Mestrado) - Curso de Direito, Universidade do Estado de Minas Gerais UEMG, Divinópolis, 2008.

OLIVEIRA, V. N. Prisões sem guardas: uma experiência liderada por grupos religiosos. In: 37o Encontro Annual da ANPOCS, 2013. Águas de Lindoia. Simpósios Pós-Graduados (SPG), 2013. Available in: <thhp://portal.anpocs.org/portal/ 
index.php?option $=$ com_docman\&task $=\mathrm{doc}$

details\&gid $=8703 \&$ Itemid $=429>$. Acesso em $18 \mathrm{de}$

novembro 2015.

OTTOBONI, M.. Vamos matar o criminoso: Método

APAC. São Paulo: Paulinas, 2014.

ROCHA, V. F. T.; LIMA, T. C. B.; FERRAZ, S. F. S. A inserção do egresso prisional no Mercado de trabalho cearense. Revista Pensamento Contemporâneo em Administração, Rio de Janeiro, v. 7, n. 4, p. 185-207, out/dez 2013.

ROSSINI, T. R. D.. O sistema prisional brasileiro e as dificuldades de ressocialização do preso. DireitoNet, Sorocaba, p.1-6, 06 jan. 2015.

SANTOS, L. C. R.. Da Assistência - Os Artigos 10 e 11 da LEP. O Método APAC e seus Doze Elementos. In: SILVA, J. R. (Org.). A execução penal à luz do método APAC. Belo Horizonte: Tribunal de Justiça, 2013. p. 364364.

SIQUEIRA, K. C. de L.; SILVA, J. M. da; ANGNES, J. S. Os sentidos do trabalho: a percepção dos agentes penitenciários. Revista de Ciências Administrativas, v. 19, n. 48, ago 2017 (no prelo).

SOARES, E. F. Uma reflexão sobre as APACs. Revista Caap, Belo Horizonte, v. XVII, n. 2, p.73-93, 2011.

TAKEMIYA, D. Y.. Prevenção, punição e ressocialização: aspectos do sistema prisional brasileiro.Revista Jus Navigandi, Teresina, p.1-17, 2015.

VERGARA, S. C.. Métodos de pesquisa em administração. 5.ed. São Paulo: Atlas, 2012. 